\title{
Kertas Saring sebagai Media Transpor Darah untuk Pemeriksaan Antibodi Rabies
}

\section{Filter Paper as Blood Media Transpor for Detection of Antibodies to Rabies}

\author{
Retno Wijayanti ${ }^{1}$, Retno Damayanti ${ }^{2}$, Sri Murtini ${ }^{2}$ \\ ${ }^{1}$ Badan Karantina Pertanian, Kementerian Pertanian, Jl. Harsono RM. No.3 Ragunan, Jakarta Selatan \\ ${ }^{2}$ Departemen Ilmu Penyakit Hewan dan Kesehatan Masyarakat Veteriner Fakultas Kedokteran Hewan, \\ Institut Pertanian Bogor, Jl. Raya Dramaga, Babakan, Dramaga, Bogor. \\ *Email : retnovet@gmail.com
}

Naskah diterima: 25 Juli 2017, direvisi: 13 Oktober 2019, disetujui: 30 November 2019

\begin{abstract}
Rabies is a zoonotic disease. Rabies protection level detection was performed using antibody titration. Blood sampling activities in the field require special handling to avoid blood lysis, the sample delivery requires a cold chain with a stable temperature. Alternative method forwhole blood sample delivery using filter paper were carried out on 48 samples from susceptible animals (dogs and cats) transpored through the Soekarno Hatta Agricultural Quarantine Center. This study was designed to investigate the feasibility of filter paper sampling of blood at temperature of $26^{\circ} \mathrm{C}$ to detect of rabies antibodies using indirect method of ELISA. The results of statistical analysis of Randomized Block Design and Tukey's test showed that the antibody titres of whole blood extracted from filter paper diluted in the PBS T $100 \mu 1$ were equivalent to antibody titres of serum. Assesment of filter paper capability has sensitivity and specificity as much as $96 \%$ and $76 \%$, positive predictive value of $67 \%$, negative predictive value of $94 \%$ and reliability level of filter paper were 0.5 is moderate category. This indicates that the filter paper can be used as an alternative method of blood transport medium for rabies ELISA test.
\end{abstract}

Key words: ELISA; Filter paper; Rabies

\begin{abstract}
Abstrak
Rabies merupakan penyakit infeksius pada hewan berdarah panas dan dapat menular ke manusia (zoonosis). Pemeriksaan kekebalan terhadap penyakit rabies dilakukan dengan mengukur titer antibodinya.. Kegiatan pengambilan sampel serum darah di lapangan memerlukan penanganan khusus agar tidak terjadi kerusakan dan mengalami lisis, sehingga dalam pengiriman sampel diperlukan rantai dingin yang harus tetap terjaga kestabilannya. Metoda alternatif pengiriman sampel darah utuh di lapangan menggunakan kertas saring dilakukan pada 48 sampel dari hewan penular rabies (anjing dan kucing) yang masuk melalui Balai Besar Karantina Pertanian Soekarno Hatta. Penelitian ini bertujuan untuk mengetahui kelayakan pengambilan sampel darah yang diserap menggunakan kertas saring pada suhu $26^{\circ} \mathrm{C}$ dalam rangka mendeteksi antibodi rabies yang diuji dengan metode indirect ELISA.

Hasil analisa statistik Rancangan Acak Kelompok dan uji lanjut Tukey ektraksi kertas saring darah utuh pada pengenceran pelarut PBS T $100 \mu 1$ memiliki hasil titer antibodi sebanding dengan titer antibodi asal serum. Penilaian kemampuan kertas saring memiliki sensitifitas sebesar $96 \%$, spesifitas $76 \%$, nilai prediktif positif $67 \%$, nilai prediktif negatif $94 \%$ dan tingkat keandalan kertas saring 0.5 dengan kategori cukup baik. Hal ini menunjukkan bahwa kertas saring cukup baik sebagai media transpor alternatif darah utuh untuk pengambilan sampel pada kondisi lapang dengan uji ELISA rabies.
\end{abstract}

Kata kunci: ELISA; Kertas Saring; Rabies 


\section{Pendahuluan}

Rabies merupakan penyakit infeksius pada hewan berdarah panas dan dapat menular ke manusia (zoonosis). Hewan rentan antara lain anjing, kucing, dan kera, bahkan rabies bisa menyerang pada hewanhewan liar seperti rakun, sikung, mangos, dan kelelawar sebagai resevoirnya (Soejodono 2004). Infeksi rabies mengakibatkan kerusakan pada sistem syaraf pusat sehingga menimbulkan kematian yang tinggi. Berdasarkan informasi data Office International des Epizooties (OIE) pada tahun 2016 hampir 70000 orang per tahun meninggal akibat kasus gigitan hewan penular rabies (HPR).

Menurut OIE (2016) dua per tiga negara-negara di belahan dunia terutama Afrika dan Asia termasuk Indonesia merupakan wilayah endemis rabies, dan umumnya merupakan negara berkembang. Penyebaran rabies mampu melewati batas negara dan benua didukung oleh perkembangan teknologi informasi dan transportasi. Peran mobilitas hewan penular rabies antar negara maupun antar area sebagai komoditas perdagangan hewan kesayangan semakin meningkat mengakibatkan semakin meningkatnya resiko penularan penyakit rabies. Dampak yang muncul akibat hal tersebut, rabies semakin sulit untuk dikendalikan. Peta sebaran penularan rabies telah menyebar hampir seluruhnya di wilayah Indonesia. Daerah yang masih bebas antara lain Nusa Tenggara Barat, Irian Jaya Barat, Papua, Kepulauan Riau, Bangka Belitung dan beberapa pulau kecil di Sumatra. Sebagian pulau Jawa telah bebas melalui pengendalian yang dilakukan dengan cara vaksinasi (Ditjennak 2010). Kejadian kasus gigitan anjing di Indonesia hingga saat ini masih tinggi. Berdasarkan data Dinas Peternakan dan Kesehatan Hewan Provinsi Kalimantan Barat dari tahun 2014 hingga 2016 tercatat 1068 kasus gigitan dan wilayah provinsi Kalimantan Barat telah ditetapkan sebagai Kejadian Luar Biasa (KLB) (Susilo 2016).

Sejak ditemukan pertama kali penyakit rabies di Indonesia pada kuda tahun 1884 oleh Schoorl, pada kerbau tahun 1889 oleh Esser dan anjing pada tahun 1890 oleh Penning (Soedijar dan Dharma 2005), hingga saat ini Indonesia masih terus berusaha untuk membebaskan penyakit tersebut dari wilayah negara Republik Indonesia. Berbagai negara telah menerapkan kebijakan program pemberantasan dan pengendalian rabies termasuk Indonesia melalui program vaksinasi, eliminasi HPR, mengendalikan transporasi dan lalu lintas HPR, pengujian laboratorium serta surveillance. Sesuai Keputusan Kepala Badan Karantina Pertanian Nomor: 87/Kpts/Kr.120/L/1/2016 tentang Petunjuk Teknis Tindakan Karantina Hewan Terhadap Hewan Penular Rabies maka salah satu upaya pencegahan masuk dan menyebarnya penyakit rabies dilakukan screening test antibodi terhadap rabies. Menurut rekomendasi OIE (2008) salah satu uji serologi yang dapat dilakukan yaitu dengan metode indirect Enzymelinked Immunosorbent Assay (ELISA). ELISA merupakan salah satu uji untuk mendeteksi antibodi yang sangat berguna terkait dengan survey epidemiologi dalam populasi besar (Xu et al., 2007). Sejauh ini tidak semua Unit Pelaksana Teknis (UPT) di lingkup Badan Karantina Pertanian memiliki sarana uji ELISA rabies. Apabila sampel berasal dari UPT yang tidak memiliki alat tersebut maka harus dikirim ke laboratorium UPT yang melakukan uji ELISA.

Kegiatan pengambilan sampel darah di lapangan sebagai bahan pemeriksaan laboratorium memerlukan penanganan khusus agar tidak terjadi kerusakan dan mengalami lisis.. Pengiriman sampel diperlukan rantai dingin yang harus tetap terjaga kestabilannya. Rantai dingin untuk pengambilan sampel di lapangan tidak selalu dapat dilakukan terutama di daerah terpencil yang prasarana dan sarananya masih kurang. Salah satu upaya mendapatkan sampel dalam kondisi baik sampai di laboratorium adalah dengan menggunakan kertas saring sebagai alternatif media transpor darah. Prior (1990) telah melakukan koleksi dan metoda penyimpanan sampel darah secara sederhana menggunakan kertas saring untuk studi epidemiologi di daerah tropis terpencil. Koleksi darah dengan menggunakan kertas saring memiliki kelebihan dapat disimpan pada suhu kamar, mudah dibawa ke laboratorium dengan resiko biohazard yang rendah dan dapat diaplikasikan pada daerah yang tidak memiliki infrastruktur memadai (Hollegaard et al., 2011). Petrini (2012) menyebutkan penggunaan kertas saring pertama kali telah dilakukan lebih dari 50 tahun yang lalu. Wasniewski et al. (2014) telah menggunakan kertas saring sebagai media transpor darah untuk menilai efektifitas vaksin rabies secara oral dengan mendeteksi titer antibodi pada hewan liar rubah dan rakun. Peneliti lain Choi et al. (2014) juga mengembangkan penggunaan kertas saring sebagai biobanking.

Uji serologi merupakan salah satu tindakan dalam membantu diagnosa laboratorium yang dipengaruhi 
oleh kualitas sampel. Sampel diharapkan tidak mudah mengalami kerusakan selama perjalanan agar diperoleh hasil pemeriksaan yang valid. Penelitian ini bertujuan menguji kemampuan kertas saring dalam mengabsorbsi darah pada suhu $26{ }^{\circ} \mathrm{C}$ sebagai salah satu alternatif media transpor untuk pemeriksaaan antibodi rabies.

\section{Materi dan Metode}

Penelitian dilaksanakan pada bulan Desember 2016 sampai dengan April 2017 di Balai Besar Karantina Pertanian Soekarno Hatta dan Laboratorium Penelitian Terpadu Departemen Ilmu Penyakit dan Kesehatan Masyarakat Veteriner Fakultas Kedokteran Hewan IPB.

\section{Alat dan Bahan}

Alat dan bahan yang digunakan dalam penelitian ini biosafety cabinet class II, ELISA reader panjang gelombang $405 \mathrm{~nm}$, kit ELISA rabies PUSVETMA, inkubator, vortek, stop wacth, mikroplat dasar $\mathrm{U}$, Micropipette volume $\leq 10 \mu 1,50 \mu 1,300 \mu 1$ dan 1000 $\mu 1$, multichannel micropipette 20-100 $\mu 1$, tabung 25 $\mathrm{ml}, 100 \mathrm{ml}$, dan $1000 \mathrm{ml}$, disposal tube, kertas saring Whatman nomor 1, plastik, larutan phosphate buffered saline Tween (PBS T) $0.05 \%$, spuit $23 \mathrm{G}$.

\section{Desain Penelitian dan Besaran Sampel}

Pengambilan sampel dengan teknik consecutive sampling berdasarkan sampel hewan penular rabies (anjing dan kucing) yang masuk melalui Balai Besar Karantina Pertanian Soekarno Hatta. Besaran sampel yang diambil berdasarkan rumus $\mathrm{n}=1.96^{2} \mathrm{PQ} / \mathrm{d}^{2}$ dengan keterangan $\mathrm{n}=$ besaran sampel, $\mathrm{P}=$ asumsi prevalensi, $Q=1-P$ dan $\mathrm{d}=$ derajat presisi (Pfeiffer 2002). Berdasarkan perhitungan tersebut diperoleh besaran sampel sebanyak 48 sampel. Hewan uji dengan status divaksin dilengkapi data dokumen buku vaksinasi rabies. Pengambilan darah melalui vena cephalica antibrachii anterior. Sampel merupakan darah utuh yang diambil menggunakan spuit dan diserap kertas saring. Volume darah utuh $0.2 \mathrm{ml}$ diserap kertas saring sampai terserap jenuh pada luasan kertas saring $3 \mathrm{~cm}$ x $1.5 \mathrm{~cm}$. Kertas saring yang digunakan adalah kertas saring Whatman nomor 1 . Kertas saring dikeringkan pada suhu $26^{\circ} \mathrm{C}$ selama 2 jam dan 3 hari selanjutnya dapat disimpan dalam kantong plastik. Pengujian ELISA dilakukan pada hari pertama dan tiga hari setelah masa pengambilan.

\section{Ekstraksi Kertas Saring}

Kertas saring dipotong menggunakan pelubang kertas (perforator) berdiameter $6 \mathrm{~mm}$. Satu cakram kertas saring dilarutkan dalam PBS Tween $0.05 \%$ pada volume $100 \mu \mathrm{l}, 200 \mu \mathrm{l}$, dan $300 \mu \mathrm{l}$. Campuran ini divortex selama 5 menit. Kemudian ekstrak kertas saring digunakan untuk uji ELISA.

\section{Pengujian Antibodi Rabies}

Pemeriksaan antibodi terhadap virus rabies pada penelitian ini menggunakan metode ELISA sesuai dengan rekomendasi OIE tahun 2008 dalam Manual of Standards for Diagnositic Test and Vaccines. Metode ELISA mempunyai spesifisitas yang baik dan sesuai penggunaannya sebagai metode uji cepat titer antibodi yang memerlukan waktu sekitar 4 jam. Titer serum ditentukan berdasarkan optical density (OD) dalam bentuk ekuivalen unit (EU) terhadap serum standar OIE. Hasil titer yang protektif ditunjukkan dengan nilai $\geq 0.6 \mathrm{EU} / \mathrm{ml}$ yang nilainya ekuivalen dengan $\geq 0.5 \mathrm{IU} / \mathrm{ml}$ sebagai standar protektif titer antibodi. Sampel serum diencerkan 1/100 dalam PBST sesuai petunjuk kit ELISA. Pengujian ELISA dilakukan pada sampel hasil ektraksi kertas saring dan sampel serum. Selanjutnya nilai titer antibodi rabies pengenceran kertas saring yang mendekati nilai titer pengenceran serum dapat digunakan sebagai standar pengenceran.

\section{Prosedur Analisis Data}

Hasil penelitian dianalisis statistik menggunakan Rancangan Acak Kelompok dilanjutkan Uji Tukey. Kemampuan kertas saring sebagai media transpor diuji dengan menentukan sensitivitas, spesifisitas, nilai prediktif positif (NPP), nilai prediktif negatif (NPN) dan analisis kesepakatan Kappa Cohen (k). Klasifikasi rentang nilai kappa dari 0 sampai dengan 1. Interpretasi nilai kappa 0.4 sampai dengan 0.6 adalah sedang, diatas 0.6 adalah baik (Pfeiffer 2002)

\section{Hasil dan Pembahasan}

Penyerapan sampel darah utuh mengalir melaui pori-pori kertas saring sebagai media transpor. Metode penyerapan darah menggunakan kertas saring mampu dilakukan karena kertas saring mengandung 90\% sampai dengan 99\% serat selulosa sebagai komponen terpenting. Jaringan kertas saring tersusun atas selulosa secara acak dan terdapat bagian yang tidak berserat sebagai kapiler sehingga memudahkan penyerapan 
cairan (Sahin dan Arslan 2008). Kertas saring dengan luas $4.5 \mathrm{~cm}^{2}$ mampu menyerap darah sejumlah 0.2 $\mathrm{ml}$, sehingga dapat diperoleh konsentrasi darah pada satu keping cakram berdiameter $6 \mathrm{~mm}$ sejumlah 12.6 $\mu 1$. Semua komponen darah yang diserap pada kertas saring akan mengalami proses penggumpalan dan tetap berada di jaringan selulosa kertas saring. Konsentrasi antibodi dalam darah yang dapat diserap kertas saring menurut Jarujamrus et al. (2012) mencapai 34\% sampai dengan $42 \%$ pada permukaan serat selulosa kertas saring. Artinya kemungkinan konsentrasi antibodi yang terdapat pada satu keping cakram kertas saring sekitar $4.2 \mu 1$ sampai dengan $5.3 \mu 1$.

Darah utuh yang diserap kertas saring diekstraksi mengunakan pelarut PBS T untuk melarutkan kembali semua komponen materi yang telah diserap. PBS T selain sebagai pelarut juga berfungsi sebagai larutan pencuci sesuai petunjuk pada kit ELISA. Menurut katalog Whatman kertas saring tersusun atas selulosa murni asetat yang dapat digunakan untuk analisis biologis, klinis, dan uji sterilitas. Membran selulosa asetat memiliki ikatan protein yang rendah dan bersifat hidrofilik sehingga komponen darah yang telah diserap dengan mudah dilarutkan kembali pada pelarut PBS T. Menurut Wang J (2014) hidrofobitas pada permukaan kertas merupakan faktor penting lainnya terutama untuk microfluidic berbasis kertas sehingga aliran cairan pada kertas dapat berpola menuju saluran aliran hidrofilik.

Standarisasi pengenceran satu cakram kertas saring menggunakan pelarut PBS $\mathrm{T}$ dengan mem- bandingkan hasil titer antibodi asal serum tersaji pada Tabel 1. Pada tabel tersebut dapat dilihat bahwa proses ekstraksi pada satu cakram kertas saring dengan volume pelarut yang semakin meningkat diperoleh nilai titer antibodi yang semakin menurun. Ektraksi dengan volume pelarut yang lebih tinggi berakibat pada penurunan konsentrasi IgG sehingga tingkat densitas optikal menurun (Natalia dan Priadi 1998).

Hasil analisa statistik menggunakan Rancangan Acak Kelompok dilanjutkan uji Tukey terlihat titer antibodi pengenceran kertas saring pada volume pelarut $100 \mu 1$ tidak berbeda nyata dengan titer antibodi asal serum. Sementara pengenceran kertas saring pada volume pelarut $200 \mu 1$ tidak berbeda nyata terhadap titer antibodi serum dan titer antibodi hasil ekstraksi pengenceran $300 \mu$ l. Hasil titer antibodi nampak berbeda nyata pada pengenceran $300 \mu$ l terhadap titer antibodi asal serum. Hasil uji ini menunjukkan bahwa titer antibodi pada kertas saring yang dilarutkan dengan pelarut PBS T $100 \mu 1$ sebanding dengan titer antibodi asal serum. Hal ini menunjukkan bahwa kertas saring dapat menyerap darah dan mengikat Ig G serta melepaskan kembali pada pelarut PBS T dengan nilai titer setara serum pada volume pengenceran pelarut $100 \mu 1$. Penyerapan darah yang merata dan jenuh sangat berpengaruh pada kesetaraan sampel kertas saring dan serum (Natalia dan Priadi 1998).

Kelompok variabel lain sebagai pembanding kemampuan kertas saring adalah lama penyimpanan kertas saring. Hasil analisa diperoleh perbedaan yang nyata antara pengujian ELISA hari pertama dan

Tabel 1. Rata rata titer antibodi sampel serum dan ekstraksi kertas saring

\begin{tabular}{|c|c|c|c|c|c|c|c|c|c|c|}
\hline \multirow[t]{2}{*}{ Kelompok } & \multirow{2}{*}{\multicolumn{2}{|c|}{$\begin{array}{l}\text { Rata rata Titer Antibodi } \\
\quad \text { Serum (EU) }\end{array}$}} & \multicolumn{8}{|c|}{$\begin{array}{l}\text { Rata rata Titer Antibodi dari } \\
\text { Ekstraksi Kertas Saring dalam pelarut PBS Tween dengan volume berbeda }\end{array}$} \\
\hline & & & \multicolumn{3}{|c|}{$100(\mu \mathrm{I})$} & \multicolumn{2}{|c|}{$200(\mu \mathrm{I})$} & \multicolumn{3}{|c|}{$300(\mu \mathrm{I})$} \\
\hline 1 Hari & \multicolumn{2}{|c|}{$5.94 \pm 0.5^{\text {ap }}$} & \multicolumn{3}{|c|}{$6.05 \pm 0.6^{\text {ap }}$} & \multicolumn{2}{|c|}{$5.41 \pm 0.5^{\mathrm{abp}}$} & \multicolumn{3}{|c|}{$4.35 \pm 0.6^{\mathrm{bp}}$} \\
\hline 3 Hari & \multicolumn{2}{|c|}{$2.61 \pm 0.4^{\mathrm{aq}}$} & \multicolumn{3}{|c|}{$2.78 \pm 0.4^{\text {aq }}$} & \multicolumn{2}{|c|}{$2.13 \pm 0.6^{\mathrm{abq}}$} & \multicolumn{3}{|c|}{$1.76 \pm 0.5^{\text {bq }}$} \\
\hline \multicolumn{11}{|c|}{$\begin{array}{l}\text { ab Angka pada baris yang sama diikuti oleh huruf yang sama tidak berbeda nyata pada selang kepercayaan } 95 \% \text {; } \\
\text { pq Angka pada kolom yang sama diikuti oleh huruf yang tidak sama berbeda nyata pada selang kepercayaan 95\%; ELISA EU } \\
\pm \mathrm{SE}\end{array}$} \\
\hline \multicolumn{11}{|c|}{ Tabel 2. Sensitivitas dan spesifisitas kertas saring dalam pelarut PBS Tween $100 \mu 1$ terhadap serum pada hari pertama } \\
\hline Kelompok & $\mathrm{n}$ & $(+)$ & $(-)$ Palsu & $(-)$ & (+) Palsu & Sv & $\mathrm{Sp}$ & NPP & NPN & $\mathrm{k}$ \\
\hline Serum & 48 & 27 & & 21 & & $100 \%$ & $100 \%$ & $100 \%$ & $100 \%$ & \\
\hline Kertas Saring & 48 & 26 & 1 & 16 & 5 & $96 \%$ & $76 \%$ & $67 \%$ & $94 \%$ & 0.5 \\
\hline
\end{tabular}

$(+)=$ positif; $(-)=$ negatif; $\mathrm{Sv}=$ Sensitivitas; Spesifisitas; $\mathrm{NPP}=$ nilai prediktif positif; NPN = nilai prediktif negatif; $\mathrm{k}=$ kappa 
hari ketiga. Smit et al. (2014) menyatakan bahwa penggunaan kertas saring sebagai media sampel uji diagnostik dipengaruhi oleh suhu tinggi dan kelembaban dalam waktu yang panjang sehingga dapat mengurangi sensitifitas uji terutama di daaerah tropis. Perubahan secara kimiawi seperti oksidasi dan degradasi proteolitik protein terjadi pada suhu sedang dan reaksi akan semakin besar pada suhu tinggi. Penyimpanan pada suhu kamar sering mengakibatkan degradasi antibodi sehingga antibodi menjadi tidak aktif, hal ini terjadi akibat adanya pertumbuhan mikroba (Johson 2012)

Perbandingan sensitivitas dan spesifisitas serum dan kertas saring sebagai media transpor darah yang diekstraksi menggunakan pelarut PBS T $100 \mu 1$ pada hari pertama ditampilkan pada tabel 2. Berdasarkan hasil diatas kertas saring memiliki sensitivitas sebesar $96 \%$ dan spesifisitasyang lebih rendah yaitu sebesar $76 \%$. Nilai sensitivitas yang tinggi pada kertas saring menggambarkan bahwa koleksi darah menggunakan kertas saring mampu digunakan untuk mendeteksi antibodi rabies dengan uji ELISA. Spesifisitas yang lebih rendah akibat masih terdapatnya sampel positif palsu. Rendahnya spesifisitas pada kertas saring terkait dengan proses ekstraksi kertas saring, karena semua materi darah ikut terlarut sehingga terbawa antibodi lain yang memiliki paratop sama dengan epitop antigen rabies. Antibodi dapat mengenali daerah antigen yang relatif kecil, kadang-kadang dapat berikatan dengan epitop serupa pada molekul lain (Harlow dan Lane 1988). Nilai spesifisitas kertas saring yang rendah untuk uji ELISA rabies diharapkan dapat meminimalkan positif palsu antibodi rabies pada hewan yang benarbenar tidak memiliki antibodi terhadap rabies. Hal ini akan berbahaya apabila digunakan untuk mendeteksi antibodi rabies pada hewan yang belum divaksinasi. Menurut Blenden et al. (1985) pengujian serologis digunakan untuk mengevaluasi status kekebalan pada hewan tervaksinasi rabies. Hewan yang telah divaksinasi diharapkan memiliki titer antibodi protektif terhadap rabies sehingga antibodi dapat merespon secara aktif bila terjadi infeksi rabies. Demikian juga menurut Cliquet et al. (2004) mengharapkan persentase positif palsu yang rendah untuk mendeteksi antibodi pada hewan dengan status telah divaksinasi rabies agar dapat menganalisa hewan yang memiliki antibodi spesifik terhadap rabies.

Nilai kemungkinan keberhasilan kertas saring dapat digunakan untuk mendeteksi positif dan negatif antibodi berdasarkan nilai prediktif positif dan nilai prediktif negatif. Probabilitas hasil antibodi prediktif positif pada kertas saring sebesar $67 \%$ lebih rendah bila dibandingkan dengan nilai prediktif negatif antibodi menggunakan kertas saring yaitu 94\%. Menurut Masson et al (2017) konsentrasi antibodi pada sampel yang diserap menggunakan kertas saring berpengaruh terhadap keberhasilan uji deteksi antibodi. Tingkat reliabilitas atau keandalan kertas saring sebagai media transpor sebesar 0.5 dan dikategorikan sedang atau cukup baik. Hal ini menunjukkan bahwa kertas saring cukup baik sebagai media transpor alternatif pada kondisi lapang untuk uji ELISA rabies.

\section{Kesimpulan}

Hasil penelitian ini menunjukkan bahwa titer antibodi dari sampel kertas saring secara optimal dapat dilakukan pengenceran pada volume pelarut PBS T 100 $\mu 1$ dengan titer antibodi mendekati sampel asal serum. Titer antibodi pada penyimpanan kertas saring di hari pertama dengan suhu $26{ }^{\circ} \mathrm{C}$ berbeda nyata dengan titer antibodi pada kertas saring dengan penyimpanan hari ketiga. Kertas saring cukup baik digunakan sebagai alternatif media transport darah untuk pemeriksaan titer antibodi rabies.

\section{Ucapan Terima Kasih}

Terima kasih penulis ucapkan kepada Badan Karantina Pertanian atas beasiswa S2 yang telah diberikan. Di samping itu, penghargaan penulis sampaikan kepada ibu Dr. Ir. Eliza Suryati Roesli, M.Si selaku Kepala Balai Besar Karantina Pertanian Soekarno Hatta yang telah memberikan ijin kepada penulis dalam pengambilan sampel untuk penelitian ini . Semoga karya ilmiah ini bermanfaat.

\section{Daftar Pustaka}

Badan Karantina Pertanian. Keputusan Kepala Badan Karantina Pertanian Nomor: 87/Kpts/ Kr.120/L/1/2016 Tentang Petunjuk Teknis Tindakan Karantina Hewan Terhadap Hewan Penular Rabies. Jakarta (ID): Badan Karantina Pertanian.

Blenden, DC., Torres-Anjel, M.J and Satalowich, F.T. (1985). Application of laboratory technology in the evaluation of the risk of rabies transmissions by biting dogs and cats. Di dalam Advances in 
animal welfare science. hlm 221-246. Fox, M.W dan Mickley, L.D, editor. Washington DC(US): The Humane Society of the United States. http:// animalstudiesrepository.org/acwp_vsm.

Direktorat Jendral Peternakan Departemen Pertanian RI. (2010). Data penyebaran rabies di Indonesia. Jakarta (ID): Direktorat Jenderal Peternakan. Kementerian Pertanian.

Choi, E.H., Lee, S.K., Ihm, C., and Sohn, H.K. (2014). Rapid DNA extraction from dried blood spots on filter paper: potential applications in biobanking. Public Health Res Perspect. 5(6): 351-357.

Cliquet, F., McElhinney, L.M., Servat ,A., Boucher, J.M., Lowings, J.P., Goddard, T., Mansfield, K.L., and Fooks, A.R. (2004). Development of a qualitative indirect ELISA for the measurement of rabies virus specific antibodies from vaccinated dogs and cats. J.Virol. Methods. 117: $1-8$.

Harlow, E. and Lane, D. (1988). Antibodies a Laboratory Manual. New York. USA: Cold Spring Harbor Laboratory.

Hollegaard, M.V., Grove, J., Grauholm, J., KreinerMøller, E., Bønnelykke, K., Nørgaard, M., Benfield, T.L, Nørgaard-Pedersen, B., Mortensen, P.B., Mors, O., et al. (2011). Robustness of genome-wide scanning using archived dried blood spot samples as a DNA source. BMC Genetics. 12:58.

Jarujamrus, P., Tian, J., Xu Li, Siripinyanond, A., Shiowatana, J., and Shen, W. (2012). Machanisms of red blood cells agglutination in antibody treated paper. The Royal Society of chemistry. 137. 2205-2210.

Johson, M. (2012). Antibody shelf life/how to store antibodies. Mater Methods. 2:120

Katalog Whatman. (2010). Filter Papers and Membranes. http//www.laboplus.pl/images/stories/ katalogi/2010_whatman_catalog_full_fnl.pdf.

Masson, J., Douglass, J., Roineau, M., Aye, K.S., Htwe, K.M., Warner, J., Graves, M. (2017). Concordance between plasma and filter paper sampling techniques for the lymphatic filariasis bm14 antibody ELISA. Tropical Medicine and Infectious Disease. 2(2): 6.
Natalia, L dan Priadi, A. (1998). Penggunaan kertas saring sebagai alat transpor sampel darah untuk uji serologi Pasteurella Multocida: Analisis dan perbandingan komposisi protein antara ekstrak kertas saring dan serum. JITV.3(3):182-187.

Office International des Epizooties. (2008). Rabies disease. Manual of standard for diagnostic techniques. France (FR). Chapter 2.1.13. Terrestrial Manual. P.304-323.

Office International des Epizooties. (2016). World Organization for Animal Health. Rabies Portal. France (FR). http://www.oie.int/animal-healthin-the-world/rabies-portal/.

Petrini, C., Olivieri, A., Corbetta, C., Olivieri, A., Cerone, R., D'Agnolo, G., and Bompiani, A. (2012). Common criteria among States for storage and use of dried blood spot specimens after newborn screening. Ann Ist Super Sanita. 48(2):119-121.

Pfeiffer, D.U. (2002). Veterinary Epidemiology an Introduction. Epidemiology Division Department of Veterinary Clinical Sciences. The Royal Veterinary College. London. UK: University of London.

Prior, T.W., Highsmith Jr, W.E., and Friedman, K.J. (1990). A model for molecular screening of newborns: simultaneous detection of Duchenne/ Becker muscular dystrophies and cystic fibrosis. Clin Chem. 36(10):1756-9.

Sahin, T.H and Arslan, M.B. (2008). A study on physical and chemical properties of cellulose paper immersed in various solvent mixtures. J.Mol.Sci. 9: 78-88.

Smit, P.W., Elliott, I., Peeling, W.R., Mabey, D., and Newton, P.N. (2014). An overview of the clinical use of filter paper in the diagnosis of tropical disseases. J.Trop.Med.Hyg. 90(2):195210.

Soedijar, I.L dan Dharma, D.M.N. (2005). Review rabies. Prosiding Lokakarya Nasional Penyakit Zoonosis. Jakarta. ID: Puslitbang Peternakan. Hlm 119-128. http://digilib.litbang.pertanian. go.id/v2/katalog/buku/P/prosiding-lokakaryanasional-penyakit-zoonosis/0/0/2005/reviewrabies. 
Soejodono. (2004). Zoonoses. Laboratorium KESMAVET Departemen Penyakit Hewan dan Kesmavet. Fakultas Kedokteran Hewan. Bogor. ID. Institut Pertanian Bogor: 129-136.

Susilo. (2016). Kasus gigitan rabies di Kalimantan Barat. http//www.antarakalbar.com.

Wang, J. (2014). Printing and characterization of inks for paper-based biosensor. Tesis. Ontario. CA: Mc Master University. https://macsphere. mcmaster.ca/bitstream/11375/ .../fulltext.pdf.
Wasniewski, M., Barrat, J., Combes, B., Guiot, A.L., and Cliquet, F. (2014). Use filter paper blood samples for rabies antibody detection in foxes and raccoon dogs. J.Virol Methods. 204:11-16.

Xu, G., Weber, P., Hu, Q., Xue, H., Audry, L., Li, C., Wu, J., and Bourhy, H. (2007). A simple sandwich ELISA (WELYSSA) for the detection of lyssavirus nucleocapsid in rabies suspected specimens using mouse monoclonal antibodies. Biologicals. 35. 297-302. 